\title{
Association between Firm Effects and the Extent of Compliance with Accounting Standards Disclosures by Government Business Enterprises in Nigeria
}

\author{
Sebastian Seddi Maimako ${ }^{1}$, Dr. Ray Ukpa Ayila ${ }^{2}$ \\ ${ }^{1}$ B.SC, M.SC, PhD, ACA, Professor, Accounting \& Finance, Department of Management, Faculty of Management Sciences, \\ University of Jos.
}

${ }^{2}$ B.SC, MBA, PhD, FCA, National Space Research and Development Agency, Federal Ministry of Science and Technology, Obasanjo Space Centre, Airport Road, Abuja, PMB 437, Garki, Abuja, Nigeria

\begin{abstract}
The reason for using accounting standards in organizations' operating activities is to provide the benchmark for maintaining accounting records and in preparing financial statements to meet the varied needs of users of financial statements. As guiding rules, accounting standards are expected to inherently influence disclosures in financial statements preparation. However, recent findings show that accounting technology is used to misrepresent earnings and assets in financial reports. Thereby making it appear as if accounting standards do not induce adequate compliance with the principles of recording transactions and preparation of financial statements. An obvious example is the reports from the Accountant General for the Federation on audited financial statements of commercialized Federal Government Enterprises (CFGE) in Nigeria over two decades. These reports have shown that financial statements have not fully complied with accounting standards requirements. The Auditor-General's reports support prior suggestions that disclosure practices of firms are shaped by firm characteristics. Prior studies' findings on this subject are divergent, varying from study to study, industry to industry and country to country. To examine this assertion, this study determined the influence of firm effects on the extent of compliance with accounting standards disclosure requirements by CFGE in Nigeria. The theoretical link between disclosure practices and firm effects was based on four theories- agency, stewardship, stakeholders, and resource dependence theories. The study used contents analysis methods for data gathering and employed Descriptive Statistics, Random Effects Least Square Dummy Variable Regression Model and Fixed Effect Least Square Dummy Variable Regression ModelAnalysis for data analysis. The results of the analysis show that with exception of five enterprises (NRC, SR-RB, A-IRB, LNRB, and UBRB) whose nature are negatively and significantly related to compliance with accounting standards disclosure requirements; the other 12 enterprises (NRC, FHA, H-JRB, $C B, L B R B, C R R B, N D R B, B-O R B, O-O R B, F R C N, N T A, N N P C$ and FAAN's) nature positively and significantly influence compliance with accounting standards disclosure requirements. The only enterprise's firm-effect that does not influence the extent of compliance with accounting standards disclosure requirements is $N A N$ with a p-value of $0.5318>0.05$ level of significance. Therefore, considering the results of this study, we can confirm that there is a statistical significant influence of firm-effects on most of the enterprises' extent of compliance with accounting standards disclosure requirements. The indication of this influence is shown by the difference between the Adjusted Coefficient of determination (Adjusted $R^{2}$ ) of model(5) and that of model (4) which used Tables 7 and 6 respectively. The Adjusted $R^{2}$ of Table 7 is 0.971058 and that of Table 7 is 0.4946 ; meaning that $47.6458 \%(97.11 \%-49.46 \%)$ of the variations in the extent of compliance with accounting standards disclosure requirements is explained by the enterprises' nature (firm effects), which were not taken into accounts in the earlier analysis in Table 6. Based on this analysis conducted, the findings showed that firm-effect has significant influence on extent of compliance with accounting standards disclosure requirements. These findings lead us to the conclusion that the special features (firm effects) of an enterprise, which include managerial style, managerial philosophy, managerial psychology, type of market, process of production and a host of others influence significantly the extent of compliance with accounting standards disclosure requirements in annual reporting. Therefore, the endogenous factors which introduce heterogeneitic factors in the efforts of compliance with accounting standards needs to be considered when the board and management is to decide on the disclosure practices of the enterprise.
\end{abstract}

Keywords: Association, firm effects, accounting standards, disclosure, Accountability, transparency, commercialized Federal Government enterprises

\section{Introduction}

The recent change from IAS to IFRS and from Public Sector Accounting Principles which emphasis Cash Basis accounting to International Public Sector Accounting Standards (IPSAS) Accrual Basis has become necessary due to the high desire to achieve transparency and accountability worldwide. These changes require that companies, both public and private, should review their entire reporting structure/framework. These include the form of financial statements preparation and presentation and the contents of these financial reports.
Globally, the demand for full financial information disclosure started with the global financial crises of the 1930s and was fuelled by the collapse of big companies like Enron towards the end of 2001 and the recent financial crisis of 2008. In Nigeria, the collapse of banks and the dwindling fortunes of government enterprises about the 1990s created the desire for full financial information disclosure and hence, improved accountability and transparency in the governance of both private and public enterprises (Ayila, 2015).The need to improve accountability and transparency in the governance of government enterprises necessitated the reforms which brought about the commercialisation of government companies (Privatization and Commercialization Act, 2004, as amended) 
The commercialization of government companies was partly due to the increase desire for higher level financial information disclosure by enterprises owned by government in order to make them accountable and transparent in financial reporting. The intention was to make these enterprises to appreciate the benefits of applying private sector commercial principles in the management of these enterprises and to move them from bureaucratic practices to commercial principles of doing business where market forces determine the parameters of competition. In addition, recent developments in the public sector, where government companies emerged for purposes of achieving certain economic goals that the civil service and the private sector have not been able to achieve independently has created sophisticated enterprises both in the nature and operating activities of these enterprises (Ayila, 2015). This has attracted the attention of the public who hitherto saw government owned companies as public goods and so, no ones' goods (Ayila, 2015). This renewed awareness was meant to ensure that the disclosure practices of government owned companies is monitored by the public who would demand that the enterprises' managements are accountable and transparent in the running of these companies.

Statutorily, all accounting standards require the disclosure of minimum relevant accounting information in the annual reports as set out in the relevant sections of the accounting standards (IAS 1.16) to assure investors that the firm is operating within the permit of relevant accounting standards. In addition, the disclosure requirements are also necessary to aid both existing and potential investors and other stakeholders in taking economic decisions that further their interest.

Accounting standards are guides to accounting records keeping and financial reporting and should ensure the enforcement of compliance with their principles. However, recent collapses of business enterprises have raised a number of questions about the inherent ability of accounting standards to force compliance with its prescriptions. For example, a comprehensive study of Nigerian listed companies by Adeyemi (2012) and the World Bank (2004) revealed that the Nigerian financial reporting practices are deficient in the observance of accounting standards. In addition, several annual reports of the Auditor-General for the Federation (AGF)on the audited accounts of commercialized enterprises (as required by section 85(2) of the 1999 Constitution of the Federal Republic of Nigeria, as amended) from 2002 to 2013showed that commercialized Federal Government enterprises are weak in the observance of relevant accounting standards in the preparation of annual accounts (Auditor-General's Annual Report- AGAR, on the Accounts of the Government of the Federation of Nigeria for the years ended $31^{\text {st }}$ December, 2002-2013). These reports emphasized that the financial statements of Ministries, ExtraMinisterial Department and Agencies did not disclose substantially, relevant items of accounting policies and other accounting information due to their inability to follow most of the relevant provisions of accounting standards in the preparation of their accounts.

Prior studies on disclosure practices of listed firms suggested that disclosure levels are associated with a number of firm's attributes. For example, firm size, industry type, leverage, audit firm size, number of shareholders, capital structure, board size and board quality(Cerf, 1961; Inchausti, 1997; and Bhayani, 2012). These findings are not congruent and consistent with one another, but divergent with each reaching varying degrees of conclusions about the influence of these internal factors on the disclosure of financial information in annual reports of firms.

In a previous study, Ayila (2015) further examined the "Association between firm size and the extent of compliance with accounting standards disclosures by Government Business Enterprises in Nigeria". He justified that firm size is an essential determinant of firms disclosure practices for the reasons that large companies have the ability to provide sophisticated accounting technologies and to engage quality auditing firms that produce quality financial reports and also due to large ownership structure, the need to meet all the needs of these users compel them to follow accounting standards diligently in preparing and reporting financial information.

He however, acknowledged in that same study that there are exogenous factors (firm effects) that determine the reaction of the firm towards any of its characteristics. This paper therefore focuses on the firm effects (nature) of the firm relationship with the extent of compliance with accounting standards disclosures.

Like Gillan (2006) and Brown, Beekes and Verhoeven (2011), this paper conveniently distinguishes between internal and external corporate governance characteristics. This distinction as we can see may be blurred as it is contingent upon the firm and its circumstances. By internal governance attributes we mean the Corporate Governance structures and processes that are within the control of the firm's shareholders and the board of directors. There are also exogenous factors which have a bearing on the extent of agency conflict and their costs. These include the underlying nature of the firm's business and its future investment opportunities, its resources and technology, the legal system and the laws of the land, financial accounting standards and their enforcement, capital markets and their operating rules and protocols and a host of others. In between the internal and external factors, the issue of endogeneitic factors exist and depending on the firm's constitution, the shareholders and the board will either separately or collectively take various corporate governance actions, including appointing the $\mathrm{CEO}$ and fixing their compensation packages, appointing the auditors and policies relating to financial reporting, choosing the kind of management style to adopt in dealing with customers, share of the market, philosophy underlying the production processes adapted and so on.

Previous researches in disclosure practices of the firm seemed to have ignored the endogenous factors (nature of the firm) which include management style to adopt in dealing with customers, share of the market, philosophy underlying the production processes which have derived influence on the characteristics of the firms attributes in determining the degree of compliance with accounting standards disclosures in financial reporting. To address these gaps, this paper examined empiricaly, the influence of firm effects 
(endogenous factors) on the extent of compliance with accounting standards disclosure requirements by Commercialized Federal Government Enterprises.

The remaining paper is organised as follows: literature review (conceptual and theoretical framework), methodology, discussion of the research, conclusion, recommendation and future of the research.

\section{Literature Review}

\section{Introduction}

There are several findings relating to the examination of accounting disclosures practices of firms. These researches are a follow up of the work of Cerf (1961). Following Cerf (1961) research, there has been increase interest of researchers in the factors that shape disclosure practices. These studies investigate a wide variety of issues such as: Corporate disclosure practices of firms, including both obligatory and voluntary disclosures of items in annual reports; the determinants of mandatory disclosures; the economic consequences of disclosure and financial analysis of accounting information.

Of recent, there is also a renewed demand for explanations about the inadequacy of accounting system especially financial reporting system's failure to signal for impending business collapses in the past three decades (Mack, 2002).A good number of disclosure studies have tried to explain why accounting standards have unfortunately not been able to give signals of the impending disaster of major international corporations like Enron, Lehman Brothers, Bear Stearns, AIG, and General Motors. Responding to this issue, Gross (2010) wrote that:

...the failure of the financial system in 2008 wasn't simply a massive failure of common sense, regulations, and leadership. It was also a failure of corporate governance. In theory, the corporate boards at Enron, Lehman Brothers, Bear Stearns, AIG, and General Motors were paid handsome sums to oversee the activity of the executives and protect shareholders' interest. In practice, they slept as the CEOs ran the companies into the ground (p. 59).

Many earlier studies of corporate governance and financial reporting focus upon particular governance component, such as the proportion of non-executive directors. For example, Abou-El Fotouh (2010) reported that the Organisation for Economic Co-operation and Development (OECD) published a document with the title "Corporate Governance: Lessons from the Financial Crisis" in which weaknesses and failures in corporate governance were seen as key contributors to the global financial crisis. Similarly, an ACCA (2009) report on corporate governance also pointed to the failures in corporate governance as contributing to the financial crisis of 2008 globally. Gallhofer (2014) reported that the corporate governance-related reasons for the current financial crises are the dysfunctional boards which did not fully understand the risks and impact associated with the strategies and activities they approved (management styles). He stated further that:

...in many cases, boards did not provide adequate monitoring of implementation, accounting, reporting and audit. The lack of appropriately qualified non-executive directors also contributed to the problem, as the broad range of skills and knowledge required to fully understand the complex financial and nonfinancial factors that influence organisational performance were not available (Gallhofer, 2014, p. 35).

Some studies have blamed corporate governance failures squarely on the deficiencies of Anglo-American corporate governance system. Gallhofer (2014) reported that it was commonly held that deficiencies of the Anglo-American corporate governance system helped engender and contributed to the global financial crisis. On the strength of this assertion some policy makers have expressed eagerness to address and overcome the corporate governance shortcomings in corporate management to bring about good corporate governance practices in companies (French, 1984; ACCA, 2009; Howson, 2009; Abou-El Fotouh, 2010; Maimako, 2010; Yonekura, Gallhofer \& Haslam, 2012; Gross, 2010; and Prey \& Cruz-Cruz, 2011).

In the United States of America (USA), the Shareholder Bill of Rights Act was introduced in the Senate in early 2009 in an attempt to strengthen the current system and respond to the issues of corporate governance failures (Howson, 2009). To reduce the prevalence of corporate governance failures, the Organisation of Economic Community and Development (OECD) issued the principles of corporate governance which have gained the international recognition as a benchmark for policy makers, investors, corporations and other stakeholders worldwide to apply in companies (Nwadioke, 2009). Nwadioke (2009) pointed out that these principles have formed a basis for corporate governance initiatives in both OECD and non-OECD countries.

In Nigeria, CBN (2006) Code of Corporate Governance is the official position on corporate governance issues especially in banks. Emphasising the importance of corporate governance, Maimako (2010) in his paper, "Principles of Corporate Governance", stated that the observance of these basic principles of corporate governance is very important in shaping investment decisions as corporations seek to increase shareholders' wealth and remain competitive. Therefore, good corporate governance behaviour is a key element in the management of enterprises including accounting reporting.

\section{Conceptual Framework}

Explaining the influence of endogenous factors on the extent of compliance with accounting standards disclosures is as difficult as trying to evaluate the reasons behind management decisions to disclose less or more items in financial reports. This difficulty arises from the means of measuring the intensity of corporate governance characteristics on disclosure practices of firms. Brown et al (2010) addressing endogeneity problems in trying to explain the influence of corporate governance on firm performance, observed that the challenges are rooted in the econometrics analysis of the data that tends to explain the causes and effects of corporate governance and financial and accounting policy decisions. For example, in many earlier studies, they based their inferences on the estimated parameters from reduced-form

\section{Volume 4 Issue 12, December 2015}


cross-sectional Ordinary Least Squares (OLS)regressions of financial decisions on corporate governance (Yermack, 1996 and Morck et al, 1988). These studies implicitly treat corporate governance as an exogenous variable in their model. For example, if the relationship between extent of compliance with accounting standards disclosures (disclosure index) or firm performance ( $\mathrm{Y}$ variables) and corporate governance or audit quality ( $\mathrm{X}$ variables) is positive, researchers concluded that any move by the firm towards better audit quality or corporate governance causes firm disclosure index or performance to improve. However, causality may run in both directions called "simultaneous causality", that is, it runs from $\mathrm{X}$ to $\mathrm{Y}$ and from $\mathrm{Y}$ to $\mathrm{X}$ (brown et al, 2010). The researcher's model may also suffer from "unobserved heterogeneity", where the identified relationships are symptoms of some unobservable factors (s) that drive both X and Y (Larcker and Rusticus, 2010). Brown et al (2010) further assert that in both of these cases the explanatory variable (s) will be endogenous and correlated with the residuals $\varepsilon$ in the regression model, for example, in the model ODI $=\alpha+\beta_{1} \mathrm{LnS}+\beta_{2} \mathrm{Le}+\beta_{3} \mathrm{~L}+\beta_{4} \mathrm{~A}+\beta_{5} \mathrm{Q}+\varepsilon$ ...(1) OLS is biased and inconsistent. It follows that any study that unreasonably ignores the possibility of endogeniety, but makes a causal argument that better corporate governance leads to better firm performance is at the very least incomplete. This phenomenon was observed in Ayila (2015) where apart from examining the influence of both internal and external characteristics of the firm on the disclosure index of the firm using OLS (random effects model), the study also used the fixed effects least square dummy variable multiple regression model to examine the effect of endogenous factors (firm effects) on disclosure index of the firm.

In addition, more recently, with the advent of large corporate governance databases, such as those of Inventory Responsibility Research Center (IRRC), composite measures are increasingly employed in the literature. The condensing of the information contained in a large number of individual governance items into a single measure, suggest that because it is unlikely a single characteristic can measure the overall quality of a firm's corporate governance; hence, a composite measure would do better (Brown et al, 2010). Although, Brown et al (2010) noted the creation and use of composite governance scores has intensified among researchers, this practice has mostly not been accompanied by a systematic and careful comparative study and reflection on its merits. To that extent such measures can make it impossible to explain conflicting results, and I add, which are normal in any social scientific environment, because such studies concern typically different individuals with varying degrees of interests and even with the same set of individuals and groups, experience and circumstances could change, so that the same study if applied to the same individuals and group at different times would certainly not give the same results.

However, the attempt to use the OLS model as described above could lead to erroneous calls for the establishment of more prospective legislations, mandating specific governance practices that can be described as "one-side fit all" opinion held by legal experts and authorities advocating globally desirable corporate governance characteristics (Coffee, 1999; Bebechuk and Hamdani, 2009).
Because, the problem of endogeneity is a real and serious one in much of the corporate governance literature, with most studies merely mentioning the possibility of endogeneity, Brown et al (2010) elaborated on ways in which researchers can address this problem, such as the fixed effects estimation and instrumental variables (IV approach). In this study we focus on one of the commonly used method "the fixed effects" estimation approach to determine the influence of firm effects on the extent of compliance with accounting standards disclosures by Federal Governmentowned Enterprises in Nigeria.

\section{Disclosure}

Disclosure is a theoretical concept that is difficult to measure directly. Hence, the literatures on disclosure offer a variety of potential proxies that purport to measure the extent of disclosure in financial reports of accounting items as prescribed by accounting standards (Hassan and Marston, 2010).Despite the abstract nature of accounting disclosures, they have recently become widely accepted means by which accountability and transparency in financial reporting about firms' financial activities can be measured (Hassan and Marston, 2010).Ayila (2015) reported that:

The imperativeness of looking at disclosure as a means of demonstrating accountability and transparency is viewed from many perspectives. One, the economic justification of disclosure which demonstrates accountability and transparency in financial reports of firms which is seen primarily from an implicit assumption in accounting and corporate financial management that investors based their investment decisions on the information released from annual accounts of firms (p. 7).

For example, Inchausti (1997) argued that all firms operate in competitive markets and stakeholders such as investors (potential or existing) and other individuals that deal with the company want to know if their investments will increase or decrease their worth. However, disclosure is key for a variety of reasons, such as accountability, transparency, economic stabilization, income distribution, value for money, effectiveness and efficiency for Government-owned companies. This peculiar attributes of this group of companies, place government companies in a unique situation about disclosure.

In addition, corporate disclosure is also useful to all users of financial statements because it aids the understanding of the information contained in financial statements. These include statements on how the company has interpreted and applied Generally Accepted Accounting Practice (GAAP) in accounting policies (Vitez, 2013).

Companies may have more disclosures listed on their financial statements depending not only on the nature and the environment in which the business is operating, but also for the purpose of meeting the various needs of different users (Ayila, 2015). For example, the depreciation methods used for business assets, the valuation method used to determine assets and liability values, information on the collectability of receivables and other items of accounting information contained in financial reports and methods used for income

\section{Volume 4 Issue 12, December 2015}


determination are all reasons for what disclosures should reveal (p. 8)

Providing information to the public is not a costless task. Among the costs of disclosures are the costs of information production and dissemination. For example, the costs of adopting an information system (International Financial Reporting Standard-IFRS) for collecting, processing data and reporting information and the costs of hiring accountants and audits firms that are qualified to give quality service (Hassan and Marston, 2010). In the public sector, the introduction of Public Financial Management Reforms which include the introduction of International Public Sector accounting Standards (IPSAS) Accrual is to improve the transparency and accountability of financial reporting of Ministries, Extra-ministerial Departments and Agencies of the three tiers of Governments (Federal, States and Local Governments). These reforms are certainly not without their costs, which include cost of training, deploying the technology, equipment, infrastructures, electronic and other communication systems. Furthermore, lawsuit costs may be incurred when a company is sued regarding its disclosure; if the information subsequently turns out to be erroneous (Skinner, 1994). Thus, a decision to provide more or less information (full or partial disclosures) to the public should in theory not be based on the affordability, but also the availability of measurable parameters for explaining the endogenous variables that work positively or negatively in the decision making process of financial reporting (Ayila, 2015).

Despite the presumption that a change in accounting technology (thus introduction of new accounting standards) would lead to better disclosure practices, some studies revealed in the past otherwise (Lawrence and Lorsch, 1967). Thereby leaving the debate open as to whether these changes are a substitute for or complementary to a firm's disclosure practices. These suggest that the literature on impact of new accounting standards mechanisms on quality and quantity of information disclosures in financial reports is divergent. Therefore, the link between corporate governance elements and disclosure of accounting information in annual accounts depends on the corporate governance style of the firm, which in turn is affected by characteristics of the firm; whether they are endogenous or exogenous or heterogeneous (Nandi \& Ghosh, 2012).

Similarly, accountability and transparency cannot be achieved without the financial reports disclosing items of accounting information that concern assets and liabilities valuation and income determination as depicted in the annual reports of firms. These items of accounting information are the results of corporate governance actions and are influenced by environmental factors, which may be positive or negative, within or outside the organisation (Ayila, 2015).

Thomas (1986) conceptualised the constraints upon entities affecting management's choice of reporting practices as falling into two major classes namely: the environment of the enterprise and the organisation's state or attributes. Lawrence and Lorsch (1967)'s suggested that the environmental factors offers a systematic approach toward the conceptualization of the variables which have a significant bearing on the similarities or differences in accounting styles and practices across firms. They also observed that the disclosure practices can be viewed as the outcome of an internal decision process of an entity, guided by accounting standards, but influenced by both internal and external situations within and around the firm.

This study investigated the effect of firm effects (endogenous variable) and elements of corporate governance which could also be among the unobserved corporate governance attributes (heterogenetic factors) on disclosure. The firm effects factors are special features of the firm, such as the managerial style, managerial philosophy, type of market, process of production and a host of others and are collectively referred to as the "firm effects" factors (Ayila, 2015 and Brown, Beekes \& Verhoeven, 2011). The independent variables of firm size and firm effects are discussed in the following sub-sections under determinants of disclosure.

\section{Determinants of disclosure}

Many studies have examined the relationship between company's characteristics and the extent of mandatory disclosures in both developed and developing countries (Ayila, 2015; Saheed, 2013; Agyei-Mensah, 2012; Bhayani, 2012; Galani, Alexandridis \& Stavropoulos, 2011; Brown et al., 2011; and Alabi, et al., 2010). The characteristics of a company are the company's attributes that explain the nature and activities of the company and they have been identified by these and other studies to cause variations in the extent of disclosure in annual reports. These characteristics are referred to in this study as determinants of disclosures in financial reports.

However, the results of these prior studies have been divergent. Based on the controversy surrounding the findings on listed companies, firm size and firm effects were selected for test in this study, given the observation of Ayila (2015) and Brown et al (2010) that endogenous factors could influence the effect of firm characteristics on compliance and could even become heterogenietic factors in the process.

\section{Firm Size}

According to intuition and empirical studies suggest that firm size positively influences mandatory disclosure practices of firms (Owusu - Ansah, 1998). On the other hand, Wallace et al (1994) admitted that although there is overwhelming support for a positive relationship between firm size and level of disclosure, the theoretical basis is unclear.

The direction of influence of firm size on extent of disclosure can be positive or negative. That is depending on the situation. On the positive side, it can be argued that since large companies usually operate over wide geographical areas and deal with multiple products and have several divisional units, they are likely to have well-built information system that enables them to track all financial and non-financial information for operational, tactical and strategic purposes (Cerf, 1961). With this type of wellstructured internal reporting system, the incremental costs of supplying information to external users will be minimal. This will make them disclose more information than their smaller counterparts.

\section{Volume 4 Issue 12, December 2015}


However, Street and Gray (2001), Wallace et al (1994) and Wallace and Naser (1995) found no such association. Wallace and Naser (1995) argued that large firms are visible and susceptible to political attacks, in the form of pressure for the exercise of social responsibility, greater regulation such as price control and higher corporate taxes and firms may react to this political action by avoiding attention which disclosure of some significant facts could bring to them. Therefore, large firms disclose less detailed information in their annual reports to avoid attention.

To evaluate the situation in Commercialised Federal Government Enterprises, one hypothesis has been formulated to assist in examining the disclosure variations in the annual reports of these enterprises. The characteristic to be tested using this hypothesis is firm size represented by total assets. To test the assertion that large firms tend to disclose more information than small firms, we formulate the hypothesis that:

\section{Hypotheses 1 \\ $\mathrm{H}_{\mathrm{o}}$}

There is no significant relationship between firm size and extent of compliance with accounting standards disclosure requirements by the reporting enterprises.

\section{Firm Effects}

The relationship between firm effects (special features) and the extent of disclosure has not been seriously addressed in earlier studies and especially Federal Government-Owned enterprises in the public sector. The special features of a firm include managerial style, managerial philosophy, type of market, process of production and a host of others. These factors tend to influence the intercepts of the regression model in an attempt to estimate the relationship between firm size and level of disclosure (Gujarati, Porter and Gunasekar, 2012).

The firm effects interact with the firm size to give different intercepts for each enterprise as against what the influence of firm size would have been, had the firm effects are not present. To determine the firm effects on each enterprise's disclosure, the Fixed Effect Least Square Dummy Variable Model is used to identify and isolate the influence of each enterprise firm effects on disclosure compliance, in order to determine the actual influence of firm size on disclosure, which previous studies seem to have ignored all this while. Therefore, our hypothesis is:

\section{Hypothesis 2}

$\mathrm{H}_{\mathrm{o}}$

There is no significant relationship between firm effects and compliance with accounting standards disclosure requirements of the reporting enterprise.

\section{Theoretical Framework}

Different theories have been used to interpret the fluctuations in the disclosure practices of firms. This has generated a big debate in the literature about which model that explains best the relationship between corporate attributes and the disclosure practices of firms (Ayila, 2015). The debate has proved that there is no single theory that provides an adequate explanation of the relationship between various corporate attributes and accounting disclosures, because each theory based on specific assumptions, explains disclosure through a particular perspective. For example, Jensen and Meckling (1976) used agency theory to explain the association between corporate attributes and disclosure. Other researchers use other theories like stakeholder theory, resource dependence theory, stewardship theory and a host of others (Galani, Alexandridis and Stavropoulos, 2011, Alsaeed, 2006)

There are major issues that emerge when theories are adopted to explain research observations. Some of them have been introduced and developed based on the specific characteristics of countries, organisations and capital markets. For example, the stakeholder approach to disclosure has been applied and relied upon in many management and accounting literatures (Ullman, 1985; Roberts; 1992 and Gray, 1997:325-364) to resolve disclosure problems. Stakeholder theory asserts that:

...the corporations continued existence requires the support of the stakeholders and their approval must be sought and the activities of the corporation adjusted to gain that approval. The more powerful the stakeholders, the more company must adapt (Gray, 1997:416)

Disclosure is thus seen as part of the dialogue between the company and its stakeholders. Gray (1995) and Gray (1997) reported that stakeholders have the right to specific information for certain decisions and they should be provided relevant information including mandatory and environmental information. The stakeholders include: creditors, employees, suppliers, analysts, government, potential investors, credit rating agencies and the general public. In addition, stakeholders have the ability to control or affect the resources of the corporations. They exhibit their power through the level of control they have over essential resources of the company (Deegan, 2004).

Agency theory provides a framework that relates company attributes and management and employee attitude towards financial disclosures. Agency theory originated from the culture of separation of organizations' management from owners. This separation creates what is known as "principalagent" relationship. The shareholders theoretically engaged the members of management team to run the organization on their behalf. The underlying assumption is that the interest of the principal and the agent is the same. However, this is not always the case. In some cases, the interests of these two groups are not in agreement with one another. Agency theory argues that senior management was likely to manipulate the information in the financial statements in its own favour by selecting accounting procedures that maximize their own utility (Jensing and Mechling, 1976).

Stewardship theory implies that the power of directors to manage the enterprise is derived from their appointment by owners. This means that the managers are required to be accountable to the owners. Stewardship theory thus suggests a collaborative approach between directors and managers. Such an approach, according to Stephen (2002) stresses service; calling for boards to advice the managers and the managers providing stewardship/accountability reports in

\section{Volume 4 Issue 12, December 2015}




\section{International Journal of Science and Research (IJSR)}

ISSN (Online): 2319-7064

Index Copernicus Value (2013): 6.14 | Impact Factor (2014): 5.611

line with the requirements of accounting standards to the owners, as is required by statutes.

Stewardship theory has been considered important because of the fiduciary relationship between the board and owners which places the board in a position to produce stewardship/accountability financial reports to meet the requirements of the owners. It draws the attention of the board to the needs of stakeholders, which include resource allocation decision-usefulness information needed to aid resource allocation decisions, such as investment, credit and risk analysis of the stakeholders.

Resource Dependence theory (RDT) refers to how the providers of external resources of organizations affect the behaviour of the organization's managers. The procurement of external resources is an important tenet of both the strategic and tactical management of any company. Organizations depend on many external resources (External factors), including labour, capital and raw materials. Organizations may not be able to come obtaining the countervailing initiatives for all these multiple resources if the management is not able to harness the external sources of these resources. Therefore, organizations should move through the principle of criticality and principle of scarcity (Drees \& Heugens, 2013) to ensure that the external sources of resources it depends on are not thwarted by the management insensitivity to recognize the dangers inherent in the influence of external parties to the firm. Critical resources are those the organization must have to function, for example, capital. In this case, the capital structure is a critical aspect of the organization.

Therefore, the stakeholder, stewardship, resource dependence and agency theories are used in this study to develop a strong theoretical base for conceptualising, identifying and explaining the relationship between firm effects and extent of compliance with accounting standards disclosure practices of firms. This is illustrated in figure 1 .

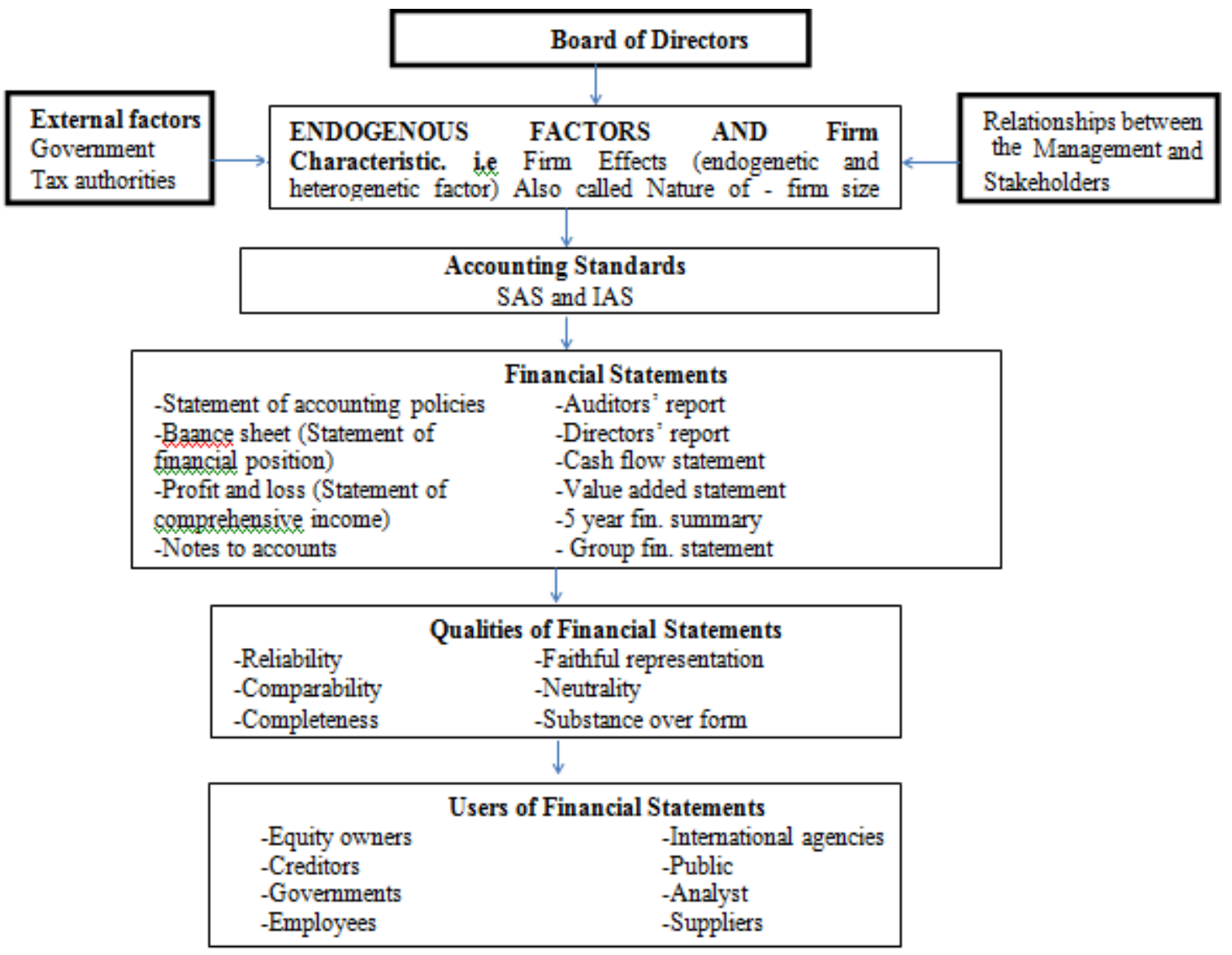

Source: Ayila (2015)

Figure 1: Conceptual Model for Studying the Relationship between Firm Effects and Extent of Compliance with Accounting Standards Disclosures by Commercialised Federal Government Enterprises in Nigeria

Figure 1 shows the conceptual model for studying the association between firm effects and extent of compliance with accounting standards disclosures by commercialised Federal Government enterprises in Nigeria. The model indicates the board as authorities responsible for preparing financial statements. The extent to which the preparation of financial statements discloses accounting items required by accounting standards, which are the guiding principles that aid the board and its management in preparing financial statements with the intention that they meet the needs of the users as they meet the qualities of financial statements depends on the firm effects; that is, the nature of the firm, a factor that endogeneitic to the firm. Based on the endogenetic nature of the firm effects, the quality of the financial statements or the extent of compliance with accounting standards in the preparation of financial

\section{Volume 4 Issue 12, December 2015}


statements is further influenced by the characteristics of the owners, the board and the management, whose behaviours determine the managerial style, managerial philosophy, marketing and production policies and share of the market (firm effects of the organisation)

\section{Empirical Studies}

The empirical research on the extent of disclosure compliance with accounting standards dated back to the 1961 studies, starting with the pioneering study of Cerf (1961). After wards further studies included Watts and Zimmerman (1990); Wallace and Naser (1995); Meek, Roberts and Gray (1995);Owusu- Ansah (1998); Street and Bryant (2000); Wong (2001); Joshi and Ramadhan (2002); Naser and Nuseibeh (2003); Akhtaruddin (2005); Adeyemi (2006); Ofoegbu and Okoye (2006); Umoren (2009); Onafalujo, Eke and Akinlabi (2011);Okafor and Ogiedu (2011); and Baser (2012) to mention a few.

However, these studies concentrated on the disclosure practices of listed companies on the Stock Exchange. Few of them studied unlisted small scale enterprises like the study of Agyei-Mensah (2012) on rural banks in Ashanti region of Ghana. These studies covered a variety of areas of disclosure, such as effect of corporate attributes on extent of disclosure in listed companies, the comparability of deferent accounting bases financial reports and disclosure andthe influence of firm characteristics on the quality of financial statements. These studies were also concerned with transparency and disclosures; observance of accounting standards and codes in Nigeria; the relationship between firms characteristics and mandatory or voluntary disclosures. However, all these studies concentrated on the study of listed companies and to some extent unregistered companies in the countries affected (Agyei-Mensah, 2012).

The empirical review also evaluated companies as represented by several constructs, such as adequacy, comprehensiveness, informative and timeliness of these disclosures. According to these studies, each of this construct suggests that the quality and extent of disclosure can be measured by an index representing the dependent variable (Adeyemi, 2006 and Umoren, 2009). The disclosure index is either weighted or un-weighted. Some indices are researchercreated and some are indices developed by other studies and are adopted by other researchers to represent the dependent variables (Umoren, 2009). Chow and Wong-Boren (1987) provided some proofs that there are no significant differences between weighted and un-weighted disclosure indices. The study asserted that weights neither affect real economic consequences on the subjects whose opinions are pooled, nor do they reflect stable perceptions on similar information.

The independent variables as identified in of the studies included profitability, asset size, method of trading shares, stock ownership, industry, frequency of external financing, stability of growth in earnings, dividends, product, degree of competition, and management as firms' characteristics that influenced the dependent variable of level of disclosure index.
Cerf (1961) as cited in Ray (1962) provides us with useful findings especially as a seminal work that identifies these relationships. However, the study failed to test the significance of the relationship in statistical terms. It also did not consider some corporations such as foreign corporations, banks, finance houses, insurance companies, real estate companies, public utilities (Ray, 1962), commercialised government companies and investment companies (Ayila, 2015). The inability of the study by Cerf (1961) to cover these other areas left a gap in literature for other studies to fill.

Singhvi and Desai (1971), Buzby (1975), McNally, Eng, and Hasseldine (1982), Cooke (1989) and several other studies examined the relationship between company characteristics and extent of disclosure in many countries' financial reporting on the premise that findings of one country may not be applicable to the unique culture and business environment of other countries.

The Nigerian financial reporting environment was empirically investigated by Umoren (2009), Adeyemi (2006), Ofoegbu and Okoye (2006), Okike (2000), and Wallace (1988). Wallace's (1988) study was one of the pioneer studies on the Nigerian corporate reporting environment relating to companies listed on the Nigerian Stock Exchange. He investigated the extent of disclosure using statutory and voluntary items similar to the studies of Buzby (1975), McNally et al. (1982) and Chow and WongBoren (1987). Wallace's choice of information items was relevant to the user group accountants, top civil servants, managers, investors and other professionals. The study defined disclosure as a dichotomous item "1" for an item disclosed and " 0 " for the item not disclosed and the scoring system was informed by its intensity. He constructed two types of disclosure indices, unweighted and weighted. The weighted disclosure index reflects the preferences of the sixuser groups. The result of the analysis revealed that companies which publish annual reports did not adequately comply with the disclosure requirements of accounting standards. The overall disclosure index revealed that there was a clear case of weakness in the disclosure practices of listed firms in Nigeria.

The revelations of the results of prior studies of listed companies in many countries and especially in Nigeria explained the importance of under-taking a different look at what really influence the decisions of management when considering the use of accounting standards in preparing financial reports. The focus of this research is to establish the relationship between firm effects; that is the nature of the enterprises, which constitutes the special features of the enterprises and the extent of compliance with accounting standards disclosures in financial statements

\section{Methodology}

\section{Research Design}

Methodology provides explanations concerning the accepted criteria for empirical objectivity and the methods and techniques used for their validation. Objectivity depends on validation and the rules of validation are explained in this study so that it provides the basis upon which the results of

\section{Volume 4 Issue 12, December 2015}




\section{International Journal of Science and Research (IJSR) \\ ISSN (Online): 2319-7064}

Index Copernicus Value (2013): 6.14 | Impact Factor (2014): 5.611

the research can be relied on. The study used content analysis research methods to collect data and regression methods to analyse data.The reason for employing the content analysis approach was that financial reports of the enterprises were used for determining the disclosure indices of the enterprises and the overall index of all the enterprises. These indices were used in multiple regression statistics as dependent variables; while firm effects were used as the independent variable.

\section{Contents Analysis Approach}

Content analysis is one of the most important yet complex research methodologies in the social sciences. It is a wide and heterogeneous set of manual or computer-assisted technique for contextualizing interpretations of documents produced by communication processes (any kind of text, written, iconic, or multimedia) or signification processes (traces and artifacts) having as the ultimate goal, the production of valid and trustworthy inferences (Krippenddorff, 2004). In adopting the content analysis approach, two categories of secondary data was used in this paper. The first is the discrete data collected with the aid of a Disclosure Index Template and converted into continuous or ratio data using the Disclosure Compliance Index Table. The indices calculated here represent the dependent variables.

The second category of data was the continuous or interval or ratio data collected from the financial statements of the enterprises. They include financial values of assets the dummy valuables of the firm effects.

There are 18 enterprises with 213 annual reports for twelve years (2002-2013). However, only 195out of 213 financial reports were obtained from the Office of the Auditor General for the Federation (Table 1). The one hundred and ninety five (195) financial statements were analysed using the Disclosure Index Checklist, Disclosure Index Template and the Corporate Attributes Template. Table 1 below shows the computation of the population of financial statements.

Table 1: The Population of Financial Statements

\begin{tabular}{|c|c|c|c|c|c|}
\hline S.No & Commercialised Federal Government Enterprises & $\begin{array}{c}\text { Number of } \\
\text { Annual Reports } \\
\text { Expected from } \\
2002-2013\end{array}$ & $\begin{array}{c}\text { Number of } \\
\text { Annual Reports } \\
\text { produced from } \\
2002-2013\end{array}$ & $\begin{array}{c}\text { Outstanding } \\
\text { Annual Reports } \\
\text { from 2002- } \\
2013\end{array}$ & $\begin{array}{c}\text { Percentage of } \\
\text { Annual Reports } \\
\text { Submitted to AGF } \\
2002-2013\end{array}$ \\
\hline 1 & Nigerian Railways Corporation & 12 & 11 & 1 & $91.67 \%$ \\
\hline 2 & Federal Housing Authority, Abuja & 12 & 11 & 1 & $91.67 \%$ \\
\hline 3 & Sokoto- Rima River Basin Development Authority, sokoto & 12 & 10 & 2 & $83.33 \%$ \\
\hline 4 & Hadejia-Jema'are River Basin Development Authority, Kano & 12 & 10 & 2 & $83.33 \%$ \\
\hline 5 & Chad Basin Development Authority, Maiduguri. & 12 & 11 & 1 & $91.67 \%$ \\
\hline 6 & Lower Benue River Basin Development Authority, Makurdi. & 12 & 11 & 1 & $91.67 \%$ \\
\hline 7 & Cross River River Basin Development Authority, Calabar. & 12 & 11 & 1 & $91.67 \%$ \\
\hline 8 & Anambra-Imo Basin Development Authority, Owerri. & 12 & 11 & 1 & $91.67 \%$ \\
\hline 9 & Niger Delta Basin Development Authority, Port Harcourt. & 12 & 11 & 1 & $91.67 \%$ \\
\hline 10 & Benin-Owena Basin Development Authority, Benin City. & 12 & 11 & 1 & $91.67 \%$ \\
\hline 11 & Oshun-Ogun Basin Development Authority, Abeokuta & 9 & 8 & 1 & $88.89 \%$ \\
\hline 12 & Federal Radio Corporation of Nigeria, Abuja & 12 & 11 & 1 & $91.67 \%$ \\
\hline 13 & Nigerian Television Authority, Abuja & 12 & 12 & 0 & $100 \%$ \\
\hline 14 & News Agency of Nigeria, Abuja & 12 & 12 & 0 & $100 \%$ \\
\hline 15 & Nigerian National Petroleum Corporation & 12 & 10 & 2 & $83.33 \%$ \\
\hline 16 & Lower Niger River Basin Devt Authority Ilorin & 12 & 11 & 1 & $91.67 \%$ \\
\hline 17 & Federal Airport Authority of Nigeria Abuja & 12 & 11 & 1 & $91.67 \%$ \\
\hline 18 & Upper Benue River Basin Devt Authority Yola & 12 & 12 & 0 & $100 \%$ \\
\hline & Total & 213 & 195 & 18 & $91.55 \%$ \\
\hline
\end{tabular}

Source: Field Work, 2015

Table 1 column 2 showed the enterprises that submitted at least seven years annual reports consistently. The total number of annual reports submitted to the AGF by December, 2013 was 195 , representing $91.55 \%$ of the total annual financial statements required for the study and 18 annual accounts $(8.5 \%)$ were still outstanding.

\section{Construction of Disclosure Index Template}

The disclosure index template includes all relevant Statement of Accounting Standards (SAS) and International Accounting Standards (IAS). The International Financial Reporting Standards (IFRS) is required to be complied with in the annual reports of enterprises by 2014 financial year and therefore was not included in the disclosure index template. Commercialized Federal Government Enterprises are included in the IFRS as Government Business
Enterprises with a reporting date of 2014. Similarly, the International Public Sector Accounting Standards (IPSAS) were not included because IPSAS are only applicable to wholly financed government owned corporations, parastatals, agencies, ministries, commissions and a host of others. Commercialized Federal Government Enterprises adopted sections 331-367 of Companies and Allied Matters Act (1990) and (2004) as amended, up to December 2013; which empowered companies to use SAS, IAS and IFRS as and when each set of the standards is applicable for preparing financial reports (TCPC Commercialization: Final Report, Volume Three, 1993).

\section{The Checklist}

SAS checklist was based on 23 mandatory SASs and contained 305 information items.

\section{Volume 4 Issue 12, December 2015}




\section{International Journal of Science and Research (IJSR) \\ ISSN (Online): 2319-7064}

Index Copernicus Value (2013): 6.14 | Impact Factor (2014): 5.611

Table 2: SAS Checklist

\begin{tabular}{|c|c|c|}
\hline Statement of Accounting Standards (SAS) & Reasons for inclusion and exclusion & Remarks \\
\hline SAS 1, SAS 2, SAS 3, SAS 4, SAS 5, SAS 6, SAS 7, SAS 8, SAS 9, & Relevant to at least one of the commercialized & Included \\
SAS 11, SAS 13, SAS 14, SAS 16, SAS 17, SAS 18, SAS 19, SAS & Federal Government enterprises & \\
22, SAS 23, SAS 24, SAS 27, SAS 28, SAS 29 and SAS 31 & & \\
\hline SAS 10, SAS 15, SAS 20, SAS 21, SAS 25, SAS 26 and SAS 30 & $\begin{array}{c}\text { Irrelevant to annual reports of Commercialized } \\
\text { Federal Government enterprises }\end{array}$ & $\begin{array}{c}\text { Excluded } \\
\text { SAS 12 }\end{array}$ \\
\hline Replaced by another standard, SAS 19 & Excluded \\
\hline
\end{tabular}

Table 3: IAS/IFRS Checklist

\begin{tabular}{|c|c|c|}
\hline Standards & Reasons for inclusion and exclusion & Remarks \\
\hline IAS 18, IAS 19, IAS 20, IAS 23, IAS 24, IAS 32, IAS & $\begin{array}{c}\text { Relevant to financial reports of commercialized } \\
\text { 39, IAS 41. }\end{array}$ & Included \\
\hline IAS 1, IAS 2, IAS 7, IAS 8, IAS 10, IAS 11, IAS 12, IAS & $\begin{array}{c}\text { Accorded substantially with the requirements of } \\
\text { 16, IAS 17, IAS 21, IAS 26, IAS 27, IAS 28, IAS 31, }\end{array}$ & Excluded \\
IAS 33, IAS 34, IAS 36, IAS 37, IAS 40, and all IFRS & $\begin{array}{c}\text { applicable due to date of commencement. } \\
\text { apriger not }\end{array}$ & \\
\hline
\end{tabular}

\section{Source: FieldWork, 2015}

\section{Data Collection}

The data was collected through the use of Disclosure Index

Template of Financial Statements as shown in table 4.

Table 4: Disclosure Scores of Financial Statements on Yearly Basis

\begin{tabular}{|c|c|c|c|c|c|c|c|c|c|c|c|c|c|c|c|}
\hline S/NO. & Organisation & 2002 & 2003 & 2004 & 2005 & 2006 & 2007 & 2008 & 2009 & 2010 & 2011 & 2012 & 2013 & $\begin{array}{c}\text { Total } \\
\text { Score }\end{array}$ & $\begin{array}{c}\text { Total } \\
\text { Exp Score }\end{array}$ \\
\hline 1 & NRC & 62 & 62 & 60 & 60 & 60 & 60 & 60 & 60 & 62 & 62 & 65 & 0 & 673 & 916 \\
\hline 2 & FHA & 83 & 83 & 83 & 85 & 76 & 75 & 73 & 74 & 75 & 74 & 79 & 0 & 860 & 1149 \\
\hline 3 & S-RRB & 47 & 48 & 45 & 48 & 48 & 47 & 45 & 46 & 47 & 47 & 0 & 0 & 468 & 657 \\
\hline 4 & H-JRB & 55 & 56 & 55 & 53 & 54 & 54 & 57 & 56 & 56 & 57 & 0 & 0 & 553 & 710 \\
\hline 5 & CB & 55 & 57 & 59 & 60 & 59 & 59 & 59 & 60 & 60 & 59 & 59 & 0 & 646 & 740 \\
\hline 6 & LBRB & 46 & 46 & 46 & 46 & 46 & 45 & 44 & 45 & 45 & 48 & 48 & 0 & 505 & 628 \\
\hline 7 & CRRB & 42 & 42 & 42 & 43 & 42 & 44 & 45 & 45 & 45 & 45 & 45 & 0 & 480 & 642 \\
\hline 8 & A-IRB & 46 & 46 & 47 & 46 & 47 & 47 & 47 & 47 & 47 & 47 & 47 & 0 & 514 & 740 \\
\hline 9 & NDRB & 51 & 51 & 53 & 53 & 53 & 53 & 53 & 54 & 54 & 54 & 55 & 0 & 584 & 676 \\
\hline 10 & B-ORB & 69 & 69 & 68 & 68 & 72 & 72 & 72 & 72 & 72 & 72 & 68 & 0 & 774 & 925 \\
\hline 11 & O-ORB & 0 & 0 & 0 & 55 & 55 & 55 & 55 & 56 & 56 & 56 & 61 & 0 & 449 & 616 \\
\hline 12 & FRCN & 47 & 47 & 47 & 47 & 47 & 47 & 48 & 49 & 50 & 53 & 53 & 0 & 535 & 693 \\
\hline 13 & NTA & 71 & 71 & 71 & 71 & 71 & 71 & 71 & 71 & 71 & 72 & 73 & 75 & 859 & 897 \\
\hline 14 & NAN & 40 & 40 & 44 & 47 & 47 & 47 & 52 & 49 & 50 & 57 & 51 & 51 & 575 & 819 \\
\hline 15 & NNPC & 177 & 179 & 179 & 179 & 179 & 179 & 179 & 179 & 184 & 184 & 0 & 0 & 1798 & 1897 \\
\hline 16 & LNRB & 31 & 31 & 31 & 31 & 31 & 31 & 31 & 31 & 31 & 31 & 31 & 0 & 341 & 539 \\
\hline 17 & FAAN & 76 & 77 & 77 & 83 & 83 & 83 & 83 & 83 & 83 & 83 & 83 & 0 & 894 & 1078 \\
\hline 18 & UBRB & 54 & 54 & 54 & 54 & 54 & 54 & 54 & 54 & 54 & 57 & 56 & 59 & 658 & 1044 \\
\hline & TOTAL & 1052 & 1059 & 1061 & 1129 & 1124 & 1123 & 1128 & 1131 & 1142 & 1158 & 874 & 185 & 12166 & 15366 \\
\hline
\end{tabular}

Field Work 2015.

\section{Estimating the Disclosure Indices}

The Disclosure Indices of the enterprises are reported in table 5. The Overall Disclosure Index is 0.79 . Table 5 also showed the disclosure indices of all the 18 enterprises as follows: Nigerian Television Authority (NTA) 96\%, Nigeria National Petroleum Corporation 95\%, Niger Delta Basin Development Authority (NDRB) 86\%, Benin -Owuma River Basin (B-ORB) 84\%, Federal Airport Authority of Nigeria (FAAN) 83\%. While Nigeria Railway Corporation (NRC), Federal Housing Authority (FHA), Chad Basin (CB), Lower Benue River Basin (LBRB), Cross River River Basin (CRRB), Ogun-Osun River Basin (O-ORB), Federal Radio Corporation of Nigeria (FRCN) and News Agency of Nigeria (NAN) have disclosure indices between $70 \%$ and
$80 \%$. Whereas the indices of Sokoto-Rima River Basin (SRRB), Anambra-Imo River Basin (A-IRB), Lower Niger River Basin (LNRB) and Upper Benue River Basin (UBRB) ranges between $60 \%$ to less than $70 \%$.

The "0s" under Sokoto-Rima River Basin Development Authority, Hadejia-Ja'maa River Basin Development Authority and Nigeria National Petroleum Corporation in 2012 and for other enterprises in 2013 represent the year that these enterprises failed to submit audited financial statements to the Auditor General's office up to the time of the researcher's final visit to the AGF's office. 
International Journal of Science and Research (IJSR)

ISSN (Online): 2319-7064

Index Copernicus Value (2013): 6.14 | Impact Factor (2014): 5.611

Table 5: Descriptive Statistics of Disclosure Index

\begin{tabular}{|c|c|c|c|c|c|c|c|c|c|c|c|c|c|c|c|c|}
\hline $\begin{array}{c}\text { S. } \\
\text { NO }\end{array}$ & Organisation & 2002 & 2003 & 2004 & 2005 & 2006 & 2007 & 2008 & 2009 & 2010 & 2011 & 2012 & 2013 & $\begin{array}{c}\text { Total } \\
\text { Score }\end{array}$ & $\begin{array}{c}\text { Expected } \\
\text { Score }\end{array}$ & $\begin{array}{c}\text { Disclosure } \\
\text { Index }\end{array}$ \\
\hline 1 & NRC & 62 & 62 & 60 & 60 & 60 & 60 & 60 & 60 & 62 & 62 & 65 & 0 & 673 & 916 & 0.73 \\
\hline 2 & FHA & 83 & 83 & 83 & 85 & 76 & 75 & 73 & 74 & 75 & 74 & 79 & 0 & 860 & 1149 & 0.75 \\
\hline 3 & S-RRB & 47 & 48 & 45 & 48 & 48 & 47 & 45 & 46 & 47 & 47 & 0 & 0 & 468 & 657 & 0.71 \\
\hline 4 & H-JRB & 55 & 56 & 55 & 53 & 54 & 54 & 57 & 56 & 56 & 57 & 0 & 0 & 553 & 710 & 0.78 \\
\hline 5 & CB & 55 & 57 & 59 & 60 & 59 & 59 & 59 & 60 & 60 & 59 & 59 & 0 & 646 & 740 & 0.87 \\
\hline 6 & LBRB & 46 & 46 & 46 & 46 & 46 & 45 & 44 & 45 & 45 & 48 & 48 & 0 & 505 & 628 & 0.80 \\
\hline 7 & CRRB & 42 & 42 & 42 & 43 & 42 & 44 & 45 & 45 & 45 & 45 & 45 & 0 & 480 & 642 & 0.75 \\
\hline 8 & A-IRB & 46 & 46 & 47 & 46 & 47 & 47 & 47 & 47 & 47 & 47 & 47 & 0 & 514 & 740 & 0.69 \\
\hline 9 & NDRB & 51 & 51 & 53 & 53 & 53 & 53 & 53 & 54 & 54 & 54 & 55 & 0 & 584 & 676 & 0.86 \\
\hline 10 & B-ORB & 69 & 69 & 68 & 68 & 72 & 72 & 72 & 72 & 72 & 72 & 68 & 0 & 774 & 925 & 0.84 \\
\hline 11 & O-ORB & 0 & 0 & 0 & 55 & 55 & 55 & 55 & 56 & 56 & 56 & 61 & 0 & 449 & 616 & 0.73 \\
\hline 12 & FRCN & 47 & 47 & 47 & 47 & 47 & 47 & 48 & 49 & 50 & 53 & 53 & 0 & 535 & 693 & 0.77 \\
\hline 13 & NTA & 71 & 71 & 71 & 71 & 71 & 71 & 71 & 71 & 71 & 72 & 73 & 75 & 859 & 897 & 0.96 \\
\hline 14 & NAN & 40 & 40 & 44 & 47 & 47 & 47 & 52 & 49 & 50 & 57 & 51 & 51 & 575 & 819 & 0.70 \\
\hline 15 & NNPC & 177 & 179 & 179 & 179 & 179 & 179 & 179 & 179 & 184 & 184 & 0 & 0 & 1798 & 1897 & 0.95 \\
\hline 16 & LNRB & 31 & 31 & 31 & 31 & 31 & 31 & 31 & 31 & 31 & 31 & 31 & 0 & 341 & 539 & 0.63 \\
\hline 17 & FAAN & 76 & 77 & 77 & 83 & 83 & 83 & 83 & 83 & 83 & 83 & 83 & 0 & 894 & 1078 & 0.83 \\
\hline 18 & UBRB & 54 & 54 & 54 & 54 & 54 & 54 & 54 & 54 & 54 & 57 & 56 & 59 & 658 & 1044 & 0.63 \\
\hline & TOTAL & 1052 & 1059 & 1061 & 1129 & 1124 & 1123 & 1128 & 1131 & 1142 & 1158 & 874 & 185 & 12166 & 15366 & 0.79 \\
\hline
\end{tabular}

Source: Field Work 2015

\section{Multiple Regression Analysis Model}

There are two multiple regression statistics that were employed to analyse secondary data, these are the Random Effects Least-Squares Dummy Variable (LSDV) model without firm effects, which was employed to test hypothesis 1-5 using Stata version 12 Software. The Fixed Effects Least-Square Dummy Variable (LSDV) was employed to analyse the firm effects using secondary data to test hypotheses 6 using Gretl version 1.9 Software. The data used in the two statistical analyses were cross-sectional and time series in nature and was arranged in a panel form using Microsoft Excel 2010.

Estimating the Random Effects Regression Coefficients

The multiple regression statistics is presented in equation (2) as:

$$
\mathrm{ODI}=\alpha+\beta_{1} \mathrm{LnS}+\beta_{2} \mathrm{Le}+\beta_{3} \mathrm{~L}+\beta_{4} \mathrm{~A}+\beta_{5} \mathrm{Q}+\varepsilon \ldots
$$

$\beta_{i}>0 \quad i=1,2, \ldots 5$.

Where:

ODI $=$ Overall Statutory disclosure index.

$\mathrm{LnS}=\mathrm{Log}$ Size represented by $\log$ of book value of total assets.

$\mathrm{Le}=$ Gearing (Leverage) represented by the ratio of total debt to total assets.

$\mathrm{L}=$ Liquidity represented by the ratio of current assets to current liabilities.

$\mathrm{A}=1$, if the audit firm is a big audit firm and 0 , if otherwise.

$\mathrm{Q}=1$, if the enterprise's principal account officers are professionally Qualified and 0, if otherwise.

$\varepsilon=$ disturbance/error term.

$\alpha=$ Regression intercept

$\beta_{\mathrm{i}}=$ parameters to be estimated.

Source: Modified from Gujarati, Porter and Gunasekar (2012)

\section{Assumptions of Multiple Regression Analysis}

a) The probability distribution of error variable is normal. b) The standard deviation of the error variable is a constant regardless of the value of the independent variable.

c) The error variable must be independent of each other

d) There is linear relationship between the dependent and at least one of the independent variables (Keller, 2005).

The test of normality of error variable distribution was conducted using Jarque-Bera Test, test of heteroscedasticity i.e. the assumption of constancy of the variance of the error variable over time was done using Breusch-Pagan / CookWeisberg test, test of Auto-correlation (Independence of Error Variable) was done using Durbin-Watson test statistics and the test of Multi-collinearity was estimated using the Variance Inflation factor (VIF). The Co-efficient of Regression and the Adjusted Co-efficient of Determination and F-ratio test was computed to test the adequacy of the data employed in the regression models.

\section{Heteroscedasticity, Auto-correlation Consistency (HAC)} Robustness Test

From the checks of regression assumptions, the results indicated that the data was not normally distributed, there was the presence of heterscedasticity and auto-correlation. To rectify these anomalies, the study adopted the suggestions of Huber (1981) and Tiku, Tan and Balakrishnan (1986). These researchers stated that in recent years, it has been recognized that the underlying distribution is in most situations, basically not normal, heterscedastic and autocorrelated, especially in Economics and Finance. The solution, therefore, is to employ efficient estimators of coefficients in the multiple regression models when the underlying assumption of auto-correlation and heteroscedasticity is violated.

This study used closed-form estimators which were efficient and also robust to plausible deviations from an assumed model. Therefore, the Heteroscedasticity and Autocorrelation Consistency (HAC) regression method of 


\section{International Journal of Science and Research (IJSR)}

ISSN (Online): 2319-7064

Index Copernicus Value (2013): 6.14 | Impact Factor (2014): 5.611

robustness was used to resolve the problems of nonnormality, auto-correlation and heteroscedasticity in the testing hypotheses $1-2$.

\section{Transformation of Firm Size Values}

In order to reduce the size of the amount of firm size, the values of firm size were transformed to natural logarithm values using equation (3) to avoid the redundancy effect of smaller values. Thus, if the value of firm size and government grant is given as firmSi then the logarithm values of the variable was given as:

Where

$$
\text { FirmSi }=\operatorname{Ln}_{\text {firmsi }}
$$

FirmSi $=$ Untransformed values of total assets and $\mathrm{Ln}_{\text {firmsi }}=$ Transformed value of total assets

The new Random Effects Multiple Regression technique that takes care of the size of firm size is given as:

Yedi $_{i t}=\beta_{0}+\beta_{1} L n(F i r m S i)_{i t}+\beta_{2} L n(L e v)_{i t}+\beta_{3}(L i q)_{I t}+\beta_{4}($ Aud $)$ ${ }_{i t}+\beta_{5}(\text { Qual })_{i t}+\varepsilon_{i t ~ . .(4)}$

Where

Yedi $=$ Yearly Enterprise's Disclosure Index

FirmSi $_{\text {it }}=$ Firm size of firm $i$ in year $t$
$\operatorname{Lev}_{\text {it }}=$ Leverage of firm $i$ in year $t$

$\mathrm{Liq}_{\mathrm{it}}=$ Liquidity of firm $i$ in year $t$

Aud $=$ Audit size of firm $i$ in year $t$

QuaL $=$ Qualification of accountants of of firm $i$ in year $t$

$\beta_{0}=$ The intercept of the function.

$\beta_{1}, \beta_{2}, \beta_{3}, \beta_{4}$ and $\beta_{5}$, =Parameters to be estimated

$\varepsilon_{\mathrm{it}}=$ Stochastic random variable (error terms)

$i=1,2,3,4, \ldots .18$

$t=1,2,3,4, \ldots . .12$

\section{RANDOM EFFECTS STATISTICS}

Table 6: Random-effects General Least Square Regression Analysis

Random-effects GLS regression

Group variable (i): org

Number of obs $=195$

R-sq: within $=0.9618$

between $=0.0265$

overall $=0.4946$

Number of groups $=18$

Random effects $\mathrm{u} \_\mathrm{i} \sim$ Gaussian $\operatorname{corr}(\mathrm{u} i, \mathrm{X}) \quad=0$ (assumed)

Obs per group: $\min =18$ $\operatorname{avg}=10.0$ $\max =10$

Wald chi2(2) $=1856.13$

Prob $>$ chi $2=0.0000$

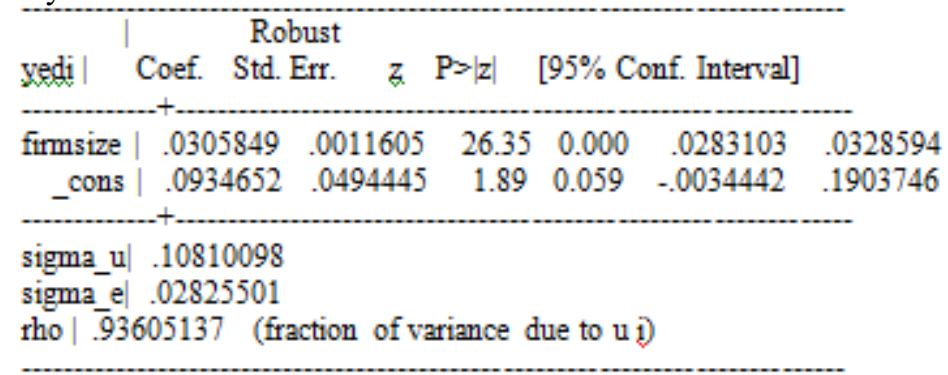

\section{Source: Ayila (2015)}

\section{Results}

Table 6 shows a Random Effects Estimation Regression analysis with the overall p-value of $0.0000<0.05$ significance-level; indicating that the model is fit. This is confirmed by the $p$-value of 0.0000 for firm size variable for hypothesis 1. This result showed that firm size is significantly related to extent of compliance with the accounting standards (disclosure Index).

This is consistent with Owusu - Ansah (1998), who reported that theory, intuition and empirical studies suggest that size positively influences mandatory disclosure practices. Therefore, firms with large amount of total assets are inclined to disclose more accounting items in their annual accounts than firms with small amount of total assets.

Singhvi and Desai (1971) advanced three basic reasons why large firms disclose more information, first, that cost of accumulating detailed information is relatively insignificant for large firms; second that the management of a larger firm is likely to realize the possible benefits of disclosure than smaller firms, and third that as small firms feel that full disclosure can endanger their competitive positions, they tried to disclose only information that will not pose a threat to their business.
However, the random effects model does not take into accounts the special features or the endogenetic factors (firm effects) of the enterprises into consideration. This aspect of the research is the subject of our paper. Thus the fixed effects influence on disclosure compliance with accounting standards takes care of the firm's nature on the disclosure compliance practices of the firm. To evaluate this aspect of the research we examined hypothesis 2 using Fixed Effect Least Square Dummy Variable Regression analysis (FELQDVRA).

\section{Fixed Effect Least Square Dummy Variable Regression Model}

To eliminate endogeneity resulting from heterogeneity i.e. unobserved variables, we take advantage of the longitudinal design (we have both cross-sectional and time series data) and employ panel data OLS regression with firm's fixedeffects (Himmelberg et al., 1999; Cremers and Ferrell, 2010). To see how this works, we decompose the residual term into a firm-specific effect that captures all-time-invariant variables (including omitted variables) that affect $\mathrm{Y}$, and the remainder that varies cross-sectionally and over time. To continue with our example, this model can be estimated using $\mathrm{N}$ dummy variables (1) one for each firm i:

Thus the model is stated as:

Yedi $_{i t}=\beta_{0}+\beta_{1} \operatorname{Ln}(\text { FirmSi })_{i t}+\beta_{2}(\text { Lev })_{i t}+\beta_{3}(\text { Liq })_{I t}+\beta_{4}(\text { Aud })_{i t}$ $+\beta_{5}\left(\right.$ Qual $_{i t}+\delta_{1} F H A_{\mathrm{i}}+\ldots+\delta_{8} A I R B_{\mathrm{i}}+\delta_{17} U B R B_{\mathrm{i}}+\varepsilon_{i t} . .(5)$ Where: 


\section{International Journal of Science and Research (IJSR)}

ISSN (Online): 2319-7064

Index Copernicus Value (2013): 6.14 | Impact Factor (2014): 5.611

Yedi $=$ Disclosure index of enterprise $i$ in year $t$

FirmSi $i_{\text {it }}=$ Firm size of firm $i$ in year $t$

$\operatorname{Lev}_{\text {it }}=$ Leverage of firm $i$ in year $t$

$\mathrm{Liq}_{\mathrm{it}}=$ Liquidity of firm $i$ in year $t$

Aud $=$ Audit size of firm $i$ in year $t$, represented by " 1 " if audit firm has international affiliation or " 0 " if it has no international affiliation.

QuaL=Qualification of accountants of firm $i$ in year $t$, represented by " 1 " if a chartered accountant and " 0 " if not a chartered accountant

$\boldsymbol{F H} \boldsymbol{A}_{i}=$ Federal Housing Authority assigned 1 if it is FHA and 0 if otherwise

$\boldsymbol{R} \boldsymbol{R} \boldsymbol{B}_{\mathrm{i}}=$ Sokoto- Rima Rivers Basin Development Authority, assigned 1 if it is RRB and 0 if otherwise

$\boldsymbol{H}-\boldsymbol{J R B}_{\mathbf{i}}=$ Hadejia-Jema'are River Basin Development Authority assigned 1 if it is H-JRB and 0 if otherwise

$\boldsymbol{C B}_{\mathrm{i}}=$ Chad Basin Development Authority assigned 1 if it is $\mathrm{CB}$ and 0 if otherwise

$\boldsymbol{L} \boldsymbol{B} \boldsymbol{R} \boldsymbol{B}_{\mathrm{i}}=$ Lower Benue River Basin Development Authority assigned 1 if it is LBRB and 0 if otherwise

$\boldsymbol{C R R}_{\mathrm{R}}=$ Cross River River Basin Development Authority assigned 1 if it is CRRB and 0 if otherwise

$\boldsymbol{A I R B}_{\mathrm{i}}=$ Anambra-Imo Basin Development Authority assigned 1 if it is AIRB and 0 if otherwise

$N D \boldsymbol{B}_{\mathrm{i}}=$ Niger Delta Basin Development Authority assigned

1 if it is NDRB and 0 if otherwise
$\boldsymbol{B}-\boldsymbol{O R B}_{\mathrm{i}}=$ Benin-Owena Basin Development Authority assigned 1 if it is BORB and 0 if otherwise

$\boldsymbol{O}-\boldsymbol{O} \boldsymbol{R} \boldsymbol{B}_{\mathrm{i}}=$ Oshun-Ogun Basin Development Authority assigned 1 if it is OORB and 0 if otherwise

$\boldsymbol{F R C N} \boldsymbol{N}_{\mathrm{i}}=$ Federal Radio Corporation of Nigeria assigned 1 if it is FRCN and 0 if otherwise

$\boldsymbol{N T} \boldsymbol{A}_{\mathrm{i}}=$ Nigerian Television Authority assigned 1 if it is NTA and 0 if otherwise

$\boldsymbol{N} \boldsymbol{A} \boldsymbol{N}_{\mathrm{i}}=$ News Agency of Nigeria assigned 1 if it is NAN and 0 if otherwise

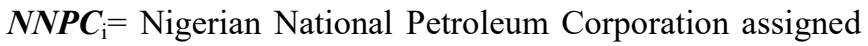
1 if it is NNPC and 0 if otherwise

$\boldsymbol{L N R B}_{\mathrm{i}}=$ Lower Niger River Basin Devt Authority assigned 1 if it is LNRB and 0 if otherwise

$\boldsymbol{F} \boldsymbol{A} \boldsymbol{A} \boldsymbol{N}_{\mathrm{i}}=$ Federal Airport Authority of Nigeria assigned 1 if it is FAAN and 0 if otherwise

$\boldsymbol{U B R} \boldsymbol{B}_{\mathrm{i}}=$ Upper Benue River Basin Devt Authority assigned 1 if it is UBRB and 0 if otherwise

$\beta_{0}=\boldsymbol{N} \boldsymbol{R} \boldsymbol{C}_{\mathrm{i}}=$ Nigerian Railway corporation assigned 1 if it is NRC and 0 if otherwise

$\beta_{1}, \beta_{2}, \beta_{3}, \beta_{4}$, and $\beta_{5}$, =Parameters to be estimated

$\delta_{1} \delta_{2} \delta_{3} \delta_{4} \delta_{5} \delta_{6} \delta_{7} \delta_{8} \ldots \delta_{17}=$ slopes of the dummy variables

$\varepsilon_{\mathrm{it}}=$ Stochastic random variable (error term)

$\mathrm{i}=1,2,3,4,5,6,7,8,9, \ldots 17$.

$\mathrm{t}=1,2,3,4,5,6,7,8,9,10,11,12$.

Table 7: Fixed-effects estimators

Fixed-effects estimates using 195 observations

Included 18 cross-sectional units

Time-series length: minimum 9, maximum 11

Dependent variable: yedi

\begin{tabular}{|c|c|c|c|c|c|}
\hline & Coefficient & Std. Error & t-ratio & $p$-value & \\
\hline Const & 0.583732 & 0.0407839 & 14.3128 & 0.00001 & $* * *$ \\
\hline firmsize & 0.0133585 & 0.00370104 & 3.6094 & 0.00041 & $* * *$ \\
\hline FHA & 0.0447715 & 0.0120127 & 3.7270 & 0.00027 & $* * *$ \\
\hline S_RRB & -0.0832583 & 0.0113681 & -7.3239 & 0.00001 & $* * *$ \\
\hline H_JRB & 0.0678403 & 0.0115718 & 5.8625 & 0.00001 & $* * *$ \\
\hline CB & 0.0810904 & 0.0112864 & 7.1848 & 0.00001 & $* * *$ \\
\hline LBRB & 0.0259016 & 0.0132842 & 1.9498 & 0.05299 & $*$ \\
\hline CRRB & 0.0372716 & 0.0113084 & 3.2959 & 0.00121 & $* * *$ \\
\hline A_IRB & -0.0889997 & 0.0111418 & -7.9879 & 0.00001 & $* * *$ \\
\hline NDRB & 0.211141 & 0.0124415 & 16.9707 & 0.00001 & $* * *$ \\
\hline B_ORB & 0.142703 & 0.0134597 & 10.6022 & 0.00001 & $* * *$ \\
\hline O_ORB & 0.00683481 & 0.0118911 & 0.5748 & 0.56627 & \\
\hline FRCN & 0.0619306 & 0.0113324 & 5.4649 & 0.00001 & $* * *$ \\
\hline NTA & 0.240469 & 0.0110656 & 21.7312 & 0.00001 & $* * *$ \\
\hline NAN & 0.00139605 & 0.0126385 & 0.1105 & 0.91219 & \\
\hline NNPC & 0.247419 & 0.0126001 & 19.6363 & 0.00001 & $* * *$ \\
\hline LNRB & -0.0900792 & 0.0111774 & -8.0590 & 0.00001 & $* * *$ \\
\hline FAAN & 0.117127 & 0.0107246 & 10.9213 & 0.00001 & $* * *$ \\
\hline UBRB & -0.106355 & 0.0113748 & -9.3500 & 0.00001 & $* * *$ \\
\hline
\end{tabular}

\begin{tabular}{|c|c|c|c|}
\hline Mean dependent var & 0.763706 & S.D. dependent var & 0.105752 \\
\hline Sum squared resid & 0.091779 & S.E. of regression & 0.024255 \\
\hline R-squared & 0.957033 & Adjusted R-squared & 0.947393 \\
\hline F(35, 156) & 99.27687 & P-value(F) & $1.29 \mathrm{e}-89$ \\
\hline Log-likelihood & 461.5670 & Akaike criterion & -851.1339 \\
\hline Schwarz criterion & -733.8641 & Hannan-Quinn & -803.6388 \\
\hline Rho & 0.005971 & Durbin-Watson & 1.817660 \\
\hline
\end{tabular}


Test for differing group intercepts -

Null hypothesis: The groups have a common intercept Test statistic: $F(17,156)=2.33524$

with p-value $=\mathrm{P}(\mathrm{F}(17,156)>2.33524)=0.00334376$

Results

The results of Table 7 revealed that there is a positive and significant relationship between dependent variable (YEDI) and firm size (firm size) with P-value $=0.0000$ at 0.05 level of significance. Based on this result, the null hypothesis that there is no significant relationship between company size and extent of compliance with accounting standards disclosure requirements by commercialized Federal Government enterprises was rejected. This result supports the theoretical basis that the size of total assets of a firm influences positively the disclosure practices of organizations (Owusu Ansah, 1998).

Table 7 also showed that the p-vales of the regression for a majority of the enterprises were $0.0000<0.05$ level of significance. For example, NRC, FHA, H-JRB, CB, LBRB, $C R R B, N D R B, B O R B, F R C N, N T A, N N P C$, and FAAN showed a positive and significant relationship with disclosure index (YEDI). This means that these enterprises' disclosure practices are influenced by firm effects (firm's special features). On the other hand, SRRB, AIRB, LNRB and $U B R B$ 's firm effects are negatively related with disclosure levels. However, O-ORB and NAN's firm effects do not have any significant relationship with disclosure index.

The estimation of the Durbin-Watson is approximately 2 and is free from autocorrelation. The F-test of the model has a pvalue $=0.0000<0.05$ level of significance, showing that the variables in the model are fit and linearly independent. The coefficient of determination $\left(\mathrm{R}^{2}\right)$ is $95.7033 \%$ and Adjusted $\mathrm{R}^{2}$ is $94.7393 \%$ meaning that the variations in the dependent variables $Y E D I$ are $94.7393 \%$ explained by the firm size and each of the enterprise firm effects (firm's special features).

The signs $*, * *$, and $* * *$ showed the results of the regression at various levels of significance. The sign $*$ showed the regression results at 0.01 level of significance. The sign ** showed the regression results at 0.05 level of significance and the sign $* * *$ showed the regression results at 0.1 level of significance.

\section{Discussion}

Our results lend support to the idea that firm size is decisive in shaping the patterns of disclosure practices of Commercialised Federal Government Enterprises. The hypothesis that there is significant relationship between firm size and disclosure practices is true. The policy implication of this is that the amount of investment in the assets of these enterprises should keep increasing and when this happens, investors and other stakeholders should believe that the disclosures in the financial statements would improve and so also the accounting information as required by accounting standards. This confirms the suggestion that firm size is the most consistently reported corporate attribute that significantly influences the disclosure practices of firms. This assertion is supported by this result, because, the enterprises that have indices above $90 \%$ are enterprises with large network of operations and have huge sums of money in assets, for example, NTA (96\%), and NNPC (95\%)(Table 5).

On the bases of individual enterprises, NTA and NNPC with disclosure indices of 0.96 and 0.95 respectively, indicate statistically that their disclosure levels are higher compared with the cross-country average disclosure benchmark of 0.91 for emerging economies like Nigeria as revealed in the literature (Tower, Hancock and Taplin, 1999). The overall disclosure index is far less than the cross-country average benchmark of $91 \%$ for emerging economies. The implication of this finding is that overall extent of disclosure compliance with the accounting standards is generally low for commercialized Federal Government Enterprises in Nigeria.

Borrowing from econometrics, Brown, Beekes and Verhoeven (2011) who stated that the problem of endogeneity is a real and serious one in much of the corporate governance literature, with most studies merely mentioning the possibility of endogeneity, we focus on one of the commonly used methods, fixed effects estimation approach.

In doing so, we eliminated the endogeneitic factors resulting from unobserved heterogeneitic factors by using the longitudinal design (with both cross-sectional and time series data) employing panel data ordinary least square (OLS) regression with firm fixed effects to analyse the data. By taken together firm size and firm effects which included the special features of a firm such as managerial style, managerial philosophy, type of market, and process of production which we referred to as endogenous factors in the FELSDVRA; the heterogeneitic factors were taken care of and those factors which were left unobserved in the analysis in table (6), for example time effect factors like changes in government regulations, taxation laws and regulatory policies and which were assumed to have been pooled in the regression equation (4)and bias the slope of the estimate because the enterprises were considered as being the same have been dealt with in the analysis in Table (7).

Therefore, considering the results of Table 7, we can confirm that there is a statistical significant relationship between firm effects of most of the enterprises and compliance with accounting standards disclosure requirements. The indication of this significant relationship is shown by the difference between the Adjusted Coefficient of determination (Adjusted $\mathrm{R}^{2}$ ) of model (5) and (4) which used Tables 7 and 6 respectively. The Adjusted $\mathrm{R}^{2}$ of Table 7 is 0.971058 and that of Table 6 is 0.4946 , meaning that 0.476458 (97.11$49.46=47.6458 \%$ ) of the variations in compliance with accounting standards disclosure requirements is explained by the enterprises' nature (firm effects), which were not taken into accounts in the earlier analysis in Table 6.

\section{Conclusion}

In considering the effect of these special features of the firm on accounting disclosures using multiple regression analysis, we allowed the heterogenetic factors among the enterprises to respond to accounting standards application in preparing financial reports of individual enterprises. It was necessary to introduce the elements of firm effects of each enterprise into

\section{Volume 4 Issue 12, December 2015}


the regression model by allowing the fixed effect intercept to vary among the enterprises in accordance with their effects on the slope. This was achieved through the use of the Fixed Effect Least Square Dummy Variable Model in which the model identified and isolated the effect of each enterprise's firm effects on disclosure compliance from that of the firm size. This helped to isolate the actual firm effect on disclosure and the effect of the firm size in all of the enterprises.

\section{References}

[1] Abou-El Fotouh, H. (2010). The Cosmetic Corporate Governance - Will Companies Learn Lessons from the Global Financial Crisis? Retrieved $24^{\text {th }}$ October, 2013 from http://ezinearticles.com/?The

Cosmetic-Corporate-Governance...Will-Companies Learn Lessons-From-theGlobal-FinancialCrisis! \&id $=4425027 \&$ opt $=$ print

[2] Adeyemi, S. B. (2006). Impact of accounting standards on financial reporting in Nigeria, unpublished $P h D$ Thesis in the Department of Accounting, University of Lagos.

[3] Agyei-mensah, B.K. (2012). Association between firm specific characteristics and level of disclosure of financial information of rural banks in the Ashanti region of Ghana; Journal of Applied Finance \& Banking, 2(1), p. 69-92.

[4] Alsaeed, K. (2006). The association between firmspecific characteristics and disclosure, Managerial Auditing Journal,21.

[5] Akhtaruddin, M. (2005).Corporate Mandatory Disclosure Practices in Bangladesh. International Journal of Accounting, 40, 399-422.

[6] Ayila, U. R (2015).Association between Corporate Attributes and the Extent of Compliance with Accounting Standards Disclosures by Commercialised Federal Government Enterprises in Nigeria. Being a $\mathrm{PhD}$ Thesis Presented to the Faculty of Management Sciences, Department of Management, University of Jos, Plateau State.

[7] ACCA, (2009).Study text for financial accounting, BPP Publishing 2009

[8] Baser, A. A. (2011). Compliance of IAS- 30: A Case Study on the Specialized Banks of Bangladesh. Research Journal of Finance and Accounting. 2(4), 1321.

[9] Bebchuk, L. A., and M. J. Roe, 1999, A theory of path dependence in corporate ownership and governance, Stanford Law Review 52, 127-70.

[10] Bhayani, S. (2012). Association between firm-specific characteristics and corporate disclosure: The case of India.A paper presented at international conference on business, Economic management and behavioural science (ICBEMBS) January, 7-8.

[11] Alabi, M.O., Onimisi, U.U., \&Enete, C. (2010). Privatization of public enterprises and Nigeria sustainable development: A review Article. Current Research Journal of Social Science, 2(3), 204-208.

[12] Brown, P; Beekes, W. \&Verhoeven P. (2011). Corporate Governance, Accounting and Finance: A Review. Accounting and Finance, 51:96-176.
[13] Buzby, S.L (1975). Company size, listed verses unlisted stocks and extent of financial disclosure; Journal of Accounting Research, 13(1), p. 16-37.

[14] Central Bank of Nigeria (2006). Code of corporate governance for banks in Nigeria post Consolidation, Abuja

[15] Cerf, A.R. (1961). Corporate reporting and investment decisions, Berkeley: University of California.

[16] Coffee, J. C., 1999, The future as history: the prospects for global convergence in corporate governance and its implications, Northwestern University Law Review 93, 641-708.

[17] Companies and Allied Matters Act, CAP.20 LFN 2004

[18] Companies and Allied Matters Act, 1990

[19] Constitution of the Federal Republic of Nigeria, 1999 as amended.

[20] Cooke, T.E. (1989). Disclosure in the corporate annual reports of Swedish companies; Accounting and Business Research, 19 (74), p. 113-541.

[21] Chow, C. W. and Wong-Boren, A. (1987).Voluntary financial disclosure by Mexican corporations; The Accounting Review.July, 62(3), p. 533-541.

[22] Cremers, M., and A. Ferrell, 2010, Thirty years of shareholder rights and firm valuation [Internet document] (Social Science Research Network) [created 1 February 2010], available from SSRN: http://papers.ssrn.com/sol3/papers.cfm?abstract_id=141 3133.

[23] Deegan, C. (2004). Environmental disclosure and share prices: A discussion about efforts to study this relationship. Accounting Forum, 28(1), 87-97.

[24] Drees, J. M., \&Heugens, P. P. M. A. R. (2013). Synthesizing and extending resource dependence theory: A meta-analysis. Journal of Management, 39, 1666-1698.

[25] French, P.A. (1984). Collective and corporate responsibility. New York: Columbia University press.

[26] Galani, D. Alexandrite, A and Stavropoulos, A (2011).The association between the firm characteristics and corporate mandatory disclosure the case of Greece, World academy of science, engineering and technology 53.

[27] Galani, D. Alexandrite, A and Stavropoulos, A (2011). The association between the firm characteristics and corporate mandatory disclosure the case of Greece; World academy of Science, Engineering and Technology 53, 2011.

[28] Gallhofer, S. (2014). Improving the effectiveness of corporate governance and accounting disclosure: Insights from Roberto Ozaki and Japan. Retieved on $28^{\text {th }} \quad$ July, 2014 from www.criticalperspectiveonacounting.com/wpcontent/uploads/2014/06/paper-cpa-055.pdf

[29] Gillan, S. L., 2006, Recent developments in corporate governance: an overview, Journal of Corporate Finance $12,381-402$.

[30] Gray, R. K. (1995a). Corporate social and environmental reporting: A review of the literature and a longitudinal study of UK disclosure; Accounting, Auditing, Auditing and Accountability Journal,8(2). 
[31] Gray, R., C. (1997). Struggling with the praxis of social accounting: Stakeholders, accountability, audits and procedures; Accounting, Auditing and Accountability Journal 10(3), p. 325364.

[32] Gross, D. (2010). Corporation killers: How inept boards of directors are ruining once great American companies. Retrieved on $16^{\text {th }}$ October, 2014 [online], from illers

http://www.newsweek.com/2010/02/02/corporationk

[33] Gujarati, D. N., Porter, D. C., \&Gunasekar, S. (2012). Basic Econometrics (5 ${ }^{\text {th }}$ ed.). Tata McGraw Hill Education Private Limited, New Delhi.

[34] Hassan, O and Marston, C. (2010).Disclosure measurement in the empirical accounting literature: $A$ review article, Working paper no.10-18, http:II www.brunnel.ac.uk/about/alad/sss/depts/economics. Economics and finance working paper series.

[35] Himmelberg, C. P., R. G. Hubbard, and D. Palia, 1999, Understanding the determinants of managerial ownership and the link between ownership and performance, Journal of Financial Economics 53, 353-384.

[36] Howson, N. C. (2009). Commentary. When Good Corporate Governance Makes Bad Financial Firms: The Global Crisis and the Limits of Private Law.108 Michigan Law Review, First Impression 44, Retrieved on $11^{\text {th }}$ July, 2012 from [online], http://www.michiganlawreview.org/assets/fi/108/ho wson.pdf

[37] Huber, P. J., (1981). Robust Statistics. John Wiley, New York.

[38] Inchaustic B. (1997). The influence of company characteristics and accountingregulation on information disclosed by Spanish firms; European accounting review, 6(1), p. 45-68.

[39] International Accounting Standard Board (IASB) 2008.

[40] Investment and Securities Act CAP.124 LFN 2004

[41] Jensen, M. C. and Meckling, W. H. (1976). Theory of the firm: Managerial behavior, agency costs and ownership structure; Journal of Financial Economics, 3, p. 305-361.

[42] Joshi, P. L. and Ramadhan, S. (2002). The Adoption of International Accounting Standards by Small and Closely held Companies: Evidence from Bahrain. The International Journal of Accounting 37, 429-440.

[43] Keller, G. (2005). Statistics for Management and Economics $\left(7^{\text {th }}\right.$ ed.). Thomson Higher Education, SouthWestern, London

[44] Krippendorff, Klaus (2004). Content analysis: An introduction to its methodology ( $2^{\text {nd }}$ ed.). Thousand Oaks, CA: Sage. p. 413.ISBN 9780761915454. Retrieved on $13^{\text {th }}$ October, 2013 from Content Analysis: An Introduction to Its Methodology or http://en.wikipedia.org/wiki/Content_analysis

[45] Larcker, D. F., and T. O. Rusticus, 2010, On the use of instrumental variables in accounting research, Journal of Accounting and Economics 49, 186-205.

[46] Lawrence, P. R. and Lorsch, J.W. (1967). Organization and Environment: managing Differentiation and Integration, Homewood, Illinois: Richard D. Irwin, Inc
[47] McNally, G.M., Eng, L.H., and Hasseldine, C.R. (1982). Corporate Financial Reporting in New Zealand: An analysis of user Preferences, Corporate Characteristics and Disclosure Practices for Discretionary Information. Accounting and Business Research 13(Winter) 11-20.

[48] Maimako, S. S., (2010). Principles of corporate governance. Abuja: Eriba Publishing co.

[49] Mack, T. (2002).The Other Enron Story. Downloaded on $23^{\text {rd }}$ September, 2014 from site http://www.webcitation.org/5tZ0qQyoO

[50] Meek, G.C., Roberts, B. and Gray, J. (1995).Factors influencing voluntary annual report disclosures by U.S., U.K. and continental European multinational corporations; Journal Studies, 26 (3), p. 555-572.

[51] Morck, R., A. Shleifer, and R. W. Vishny, 1988, Management ownership and market valuation: an empirical analysis, Journal of Financial Economics 20, 293-315.

[52] Naser, K and Nuseibeh, R. (2003). Quality of Financial Reporting: Evidence from the Listed Saudi Nonfinancial Companies.The International Journal of Accounting, 38, 41-69.

[53] Nandi, S., \&Ghosh, S. K (2012). Corporate Governance attributes firms characteristics and the level of corporate disclosure: Evidence from the Indian Listed Firms. Decision Science Letters, 2, 45-58.

[54] Nwadioke, E., (2009) Global financial crisis: Roles and challenges of corporate governance. Zenith Economic Journal, Nigeria.4(4), 28-37.

[55] Ofoegbu, G. and Okoye, E. (2006). The relevance of accounting and auditing standards in corporate financial reporting in Nigeria: Emphasis on compliance; The Nigerian Accountant, 39(4) p. 4553.

[56] Okafor, C. and Ogiedu, K. O. (2011). Potential Effects of the Adoption and Implementation of International Financial Reporting Standards (IFRS) in Nigeria.JORIND 9(2) December 2011. ISSN 15968308. Downloaded December 20011from www.transcampus.org., www.ajol.info/journals/jorind

[57] Okike, E. N. M. (1989). Extension of information in accounting reports: An investigation; Nigerian Financial Review, 2(3), p. 38-55

[58] Onafalujo, A.K., Eke, P. O. and Akinlabi, B. H. (2011). Impact of International Financial Reporting Standards on Insurance Management in Nigeria.Middle Eastern Finance and Economics. ISSN: 1450-2889 Issue 12 (2011). Eurojournals Publishing, Inc. Downloaded January 2012 from http://www.eurojournals.com/MEFE.htm

[59] Owusu-Ansah, S. (1998). The impact of corporate attributes on the extent of mandatory disclosure and reporting by listed companies in Zimbabwe; The International Journal of Accounting, 33(5), p. 605-631.

[60] Prey, W., \& Cruz-Cruz, J. (2011). Different approaches to corporate governance. Retrieved November, 2013 from http://cnx.org/content/m17367/1:5/

[61] Ray, D. D. (1962). Corporate Reporting and Investment Decisions by A.R. Cerf, Book Review in The Accounting Review, 37(3) 595-596. 


\section{International Journal of Science and Research (IJSR) \\ ISSN (Online): 2319-7064}

Index Copernicus Value (2013): 6.14 | Impact Factor (2014): 5.611

[62] Roberts, R. W. (1992). Determinants of corporate social responsibility disclosure: An application of stakeholders' theory; Accounting, Organizations and Society, 17(6), p. 565-612.

[63] Saheed, Z. (2013). Impact of globalisation on corporate governance in developing economics: A theoretical approach. Journal of Business and Management .2 (1), $1-10$

[64] Singhvi, S.S and Desai, H.B. (1971).An empirical analysis of the quality of corporate financial disclosure; The Accounting Review, 46(1) p.129-138.

[65] Skinner, D.J. (1994). Why firms voluntarily disclose bad news; Journal of Accounting Research, 32(1), p. 38-60.

[66] Stevens, J. P. (2002). Applied multivariate statistics for the social sciences $\left(4^{\text {th }}\right.$ ed.). Mahwah, NJ: LEA.

[67] Street, D. L. and S. J. Gray (2001). Observance of international accounting standards: Factors explaining non-compliance; Association of chartered certified accountants, research report 74. retrieved August 2012, from http://www.accaglobal.com

[68] Street, D.L. and Bryant, S.M. (2000). Disclosure level and compliance with IASs: A comparison of companies with and without U.S. listings and fillings; The International Journal of accounting 35(3), p. 41-69.

[69] Thomas, A. P. (1986). The contingency theory of corporate reporting: Some empirical evidence. Accounting, Organization and Society, 11(3), 253-270.

[70] Technical Committee on Privatisation and Commercialisation (TCPC) Act, (1990) (as amended)

[71] Tiku, M. L., Tan, W.Y., \&Balakrishnan, N., (1986). Robust inference. New York: Marcel Dekker.

[72] Tower, G., Hancock, P., \&Taplin, R. H. (1999). A regional study of listed companies' compliance with international acoounting standards; Accounting Forum,23(3), 293-305.

[73] Ullmann, A. A. (1985). Data in search of a theory: A critical examination of the relationships among social performance, social disclosure and economic performance of the U.S firms; Academy of Management Review 10(3), p. 540-557.

[74] Umoren, A.O. (2009) Accounting disclosures and corporate attributes in Nigerian listed Companies, unpublished PhD Thesis, Department of accounting, Convenant University,

Ota, Ogun State.

[75] Vitaz, O (2013). Accounting disclosure information, retrieved on $24^{\text {th }}$ January, 2013 from http://www.ehow.com/about 6474551-Html,.

[76] Wallace, R. S. O. (1988). Corporate Financial Reporting in Nigeria.Accounting and Business Research, Autumn 18(72) 352-362.

[77] Wallace, R.S.O and Naser, K. (1995). Firm-specific determinants of the comprehensivenessof mandatory disclosure in the corporate annual reports of firms listed on the stock exchange of Hong Kong; Journal of Accounting and Public Policy, 14, p.311-368.

[78] Wallace, R. S. O., Naser, K. and Mora, A. (1994).The relationship between the comprehensiveness of corporate annual reports and firm characteristics in Spain; Accounting and Business Research, 25 (97), p. 41-53.
[79] Watts, R. L. and Zimmerman, J. L. (1990). Positive accounting theory: A ten year perspective; The Accounting Review, 65(1), p. 131-156.

[80] World Bank, (2004).Report on the observance of standards and codes (ROSC) in Nigeria: Nigeria's accounting standards are out-dated. Retrieved November, from http://www.allafrica.co/storiesorhttp://www.eu.wiley.co m/wileyCOA/section/id_810753.html

[81] Yermack, D., 1996, Higher market valuation of companies with a small board of directors, Journal of Financial Economics 40, 185-211.

[82] Yonekura, A., Gallhofer, S., \&Haslam, J. (2012). Accounting Disclosure, corporate governance and the battle for markets: The case of trade negotiations between Japan and the U.S., Critical Perspectives on Accounting, 23(4-5), 312-31 